\title{
The incubation process for the creation of viable firms: the case of ARCA Consortium
}

\section{Gandolfo Dominici}

Business Systems Laboratory, Via Circumvallazione $77-83100$ Avellino, Italy and

Department SEAS, University of Palermo, viale delle Scienze ed. 13 - 90128 Palermo, Italy

Email: gandolfo.dominici@libero.it

\section{Gabriella Levanti*}

Department SEAS, University of Palermo, viale delle Scienze ed. 13 - 90128 Palermo, Italy

Email: gabriella.levanti@unipa.it

Corresponding author

\begin{abstract}
The aim of this study is to demonstrate that academic incubators play a key role in firm viability. This study develops a new analytic systemic framework that reveals the processes and factors that determine the effectiveness of the incubation process supported by university incubators. We analyse the effectiveness of the incubation process in the incubator of the ARCA Consortium by means of a single case study with an embedded design. In this study, adopting a systemic perspective, we shift the focus from the firm to the context, shedding light on the systemic actions that create the prerequisite conditions for the achievement of the firms' viability.
\end{abstract}

Keywords: academic incubator; spin-off; viable systems approach; VSA; ARCA Consortium; innovative start-up; entrepreneurship.

Reference to this paper should be made as follows: Dominici, G. and Levanti, G. (2015) 'The incubation process for the creation of viable firms: the case of ARCA Consortium', Int. J. Markets and Business Systems, Vol. 1, No. 1, pp.4-27.

Biographical notes: Gandolfo Dominici is the Scientific Director and a co-founder of the Business Systems Laboratory. He is a board member of the World Organisation for Systems and Cybernetics (WOSC) and of the Consorzio Universitario di Economia Industriale e Manageriale (CUEIM). Since 2004, he is the Chair of Marketing at the Department SEAS of the University of Palermo (Italy). He is the author of more than 50 published articles and books. He is the Editor-in-Chief of three and member of the editorial board of 13 international journals. His main research interests are: marketing, e-marketing, new product development, systems thinking and organisational cybernetics. 
Gabriella Levanti is an Assistant Professor of Business Management at the Department SEAS, Polytecnic School of the University of Palermo. Her research interests are: business management, complex networks, social network analysis and tourism.

\section{Introduction}

According to the principles of the knowledge economy, research and innovation are the main strategic assets behind the competitiveness of the country or (at a higher scale) a geopolitical system.

From the point of view of the enterprise system, the main transformations induced by the knowledge economy can be summarised as follows:

- the competitive advantage is based on the driver of 'knowledge' included in science-based products and services, rather than on the traditional drivers of production (Chiesa and Piccaluga, 1998)

- the process of technological innovation is no longer the mere result of risky and expensive internal research and development (R\&D) activities, but is conceived as a systemic, open, and collaborative activity (Chesbrough, 2003)

- the main driver of success is not the simple availability of knowledge (Hwang and Horowitt, 2012), but the ability to better combine different knowledge to create a suitable offer for the markets.

In this context, we can see the birth of the 'scientist-entrepreneur' - a researcher committed to transforming the scientific advancements that result from his or her research into business activities that can take advantage of their potential in the markets.

This trend is emerging in particular in those universities which, in the so-called 'second academic revolution' (Etzkowitz, 2001), have taken up the mission to commercialise the knowledge created inside their labs, alongside their traditional primary activities of teaching and research.

This third primary activity characterises the 'entrepreneurial university' which, together with the business environment and the government, represents the third actor of the 'triple helix' that fosters economic development (Etzkowitz et al., 2000; Etzkowitz and Leydesdorff, 2000).

Traditionally, the technological transfer from universities to the market went through the granting of patents to the industrial system; patents are a valuable mean for transferring explicit knowledge, but cannot transfer tacit knowledge. Academic spin-offs and highly innovative start-ups can overcome this limit and transfer tacit knowledge by involving the very researcher who created the tacit knowledge and is its only holder (Lockett et al., 2003, 2005; Moray and Clarysse, 2005; Thursby and Thursby, 2002; Wright et al., 2004a, 2004b).

Nevertheless, in the case of both highly innovative start-ups and academic spin-offs, the lack of entrepreneurial skills represents a severe constraint on the viability of these firms. As a consequence, such firms - particularly in the start-up phase - are frequently not able to operate autonomously in the markets, being strongly dependent on the social 
and business environment. They need 'cultural humus' (in the rainforest metaphor of Hwang and Horowitt, 2012) to enable the entrepreneurial way of thinking and to offer services and structures to support business innovation.

Academic incubators can give a relevant contribution to creating this 'cultural humus' and supporting spin-off firms by offering to developing business on-site facilities to aid development. Such assistance may often comprise the office space, management, and consultancy advice, along with ICT systems that, at the business plan and seed stages, a new venture may not be able to afford.

This paper aims to answer to the following research question:

RQ Can the incubation process help academic spin-offs and innovative start-ups to become successful companies?

In order to answer this question, we analyse the incubation process and the context in which firms operate according to the viable systems approach (VSA). We then examine the empirical evidence relating to innovative firms that have already been supported by the $\mathrm{ARCA}^{1}$ incubator.

Through empirical evidence, by means of a single case study with embedded design, we show how academic incubators are effective instruments for fostering the viability of highly innovative firms. The effectiveness of the incubation process is demonstrated by the high number of spin-offs that, following incubation, are able to stand alone in the market and to find consonance with the relevant suprasystems.

\section{Theoretical background}

\subsection{Foundations of the VSA}

The VSA is a systemic approach to business theory that has become increasingly prominent in Italian academic circles in recent decades. With its roots in systems thinking, the VSA reads observed actors and their relations with their contexts by analysing the relationships between fundamental elements (Barile and Polese, 2011; Dominici and Palumbo, 2013).

As a multidisciplinary theory, the VSA draws on several key concepts derived from previous studies in cybernetics, and in particular from Beer's viable system model (VSM) and Miller's living systems theory (LST).

According to Golinelli (2010), the VSA recognises an organisation as an open system that is goal-oriented, organic, autopoietic, cognitive, and cybernetic.

As in VSM, the VSA considers a firm to be a viable system when it has the ability to constantly develop its survival capability. Hence, according to the VSA, survival is the main goal of a firm.

Survival depends on the effectiveness of the interactions between the system, its parts, and the external agents in the business arena. Therefore, the firm is a system that needs to interact (through consonance) with other external relevant systems (the 'suprasystems') and to have internal cohesion (resonance) between its 'subsystems'.

The 'suprasystems' are systems in the environmental context that are evaluated as relevant by the 'organ of governance', which is the decider (as in Miller, 1978) directing the strategic activity, and the main actor in the start-up phase of the life of the firm.

The VSA is based upon ten fundamental concepts (Barile and Polese, 2010): 
1 Systems approach: Individuals, organisations, and social institutions can all be understood as systems that consist of elements directed towards specific goals (Beer, 1975).

2 Systems hierarchy: At a system level (of level L), the organ of governance identifies a number of suprasystems positioned at a higher level $(L+1)$, and a number of subsystems, to be found at a lower level $(\mathrm{L}-1)$.

3 Reductionism and holism: Given the limits of our brains in interpreting complex phenomena, we require a synthesis of both a reductionist analytical view aimed at identifying the relevant elements and their relationships, and of a holistic perspective for understanding the system as a whole.

4 Open systems and system boundaries: The viable system must be able to open its boundaries in order to connect with other systems and to exchange information and resources. Hence, the system boundary may be seen as a changing according to the system's evolutionary dynamics (Beer, 1975).

5 Autopoiesis, homeostasis, and self-regulation: Every living system has its own internal autopoietic, self-organising system (Maturana and Varela, 1975). A viable system has the capability of 'homeostasis' - that is, it can maintain its identity by not excessively changing its internal features, seeking the state of equilibrium (Beer, 1975).

6 System structure: Each system is constituted of functional parts that possess precise roles, activities, and tasks. The shift from structure to system implies shifting perspective from stationary to dynamic, as the focus moves from the parts to a holistic view of the whole.

7 Consonance and resonance: The term 'consonance' refers to the compatibility between systems. System survival requires internal cohesion if it is to achieve and maintain internal harmony. This is called 'resonance', and refers to elements working in a distinctive manner for a sole purpose. In other words, resonance can be defined as harmonious systemic interaction, while consonance is structural and relational (Barile, 2008).

8 System viability: Viability is the ability of the system to survive. In order to be viable, a system must be both consonant with its context and internally resonant. To achieve this, the system can dynamically adjust its structure and behaviour.

9 Adaptation and relationship development: Viability is related to the system's competitiveness and co-creation capability. Competitive behaviour entails the ability to recognise and manage functions and relationships, to create communication channels, to organise information flows, and to harmonise enterprise development with the context (Barile and Gatti, 2007; Christopher, 2007).

10 Complexity and decision-making: The decision-maker must be capable of discerning between 'variety' (possible variants that a phenomenon might present at a given time); 'variability' (observed changes in variety over time); and 'indeterminacy' (the possibility of not fully understanding a given phenomenon) (Golinelli, 2010). 


\subsection{The VSA conceptual matrix}

The VSA conceptual matrix (Barile and Di Nauta, 2011) describes the main steps towards the viability of the firm.

According to this model, the path to viability passes through the following phases:

- The business idea (BI) defines the basic guidelines that portray the potential of a firm. This phase does not follow a strict formal scheme.

- The general organisation scheme (GOS) is the design of the project, which recognises the mechanisms of the relations with the context.

- The logical structure (LS) is a formal representation of the BI.

- The physical structure (PS) is the crystallisation of the LS through the identification of parts that can carry out processes.

- The extended structure (ES) entails an external perspective of analysis. The definition of the ES allows a better understanding of the potential structural, coupled with the components of external entities.

- The defined organisation scheme (DOS) represents a design of the possible relations and interactions between the internal and external agents. The DOS emphasises the design of the processes.

- The specific structure (SS) is derived from the extended scheme. It may be defined as the location identified by the decision makers (i.e., the organ of governance) in order to achieve the business system goals.

- The viable system (VS): the creation of a SS allows the emergence of the viable firm as a viable part of the economic system.

\subsection{The VSA as a method for analysing research spin-offs}

Although the innovative spin-off is the main agent of innovation, to better understand its relevance to the innovation system, it is necessary to consider its relations with the relevant suprasystems and the flows of knowledge that promote innovation.

The VSA (Golinelli, 2010), through its relational and holistic perspective, helps shed light on the synergic nexus among the various agents involved in the process of knowledge transfer and entrepreneurial implementation, from research labs to the markets.

The VSA highlights the relational links between the firm and its context, and analyses the evolutionary dynamics of these relations towards viability.

\section{Research spin-offs and the role of incubation process}

Research spin-offs are a formidable way to give market value to scientific research. They can be conceived of as 'relational bridges' (Golinelli, 2011) between the research systems and the market.

According to Chiesa and Piccaluga (1998), research spin-offs are entrepreneurial activities born by division from academic environments or public research institutions. 
Hence, the category of research spin-off includes both academic spin-off and innovative firms deriving from research institutions.

As we stated above, the main constraint on the development of this kind of firm is the non-entrepreneurial attitude of the researchers. The types of capabilities that are usually deficient in this kind of entrepreneurial initiatives are:

- Managerial and organisational skills: The job of the researcher is usually far from the entrepreneurial way of thinking; most researchers thus do not have adequate managerial and organisational expertise to manage a firm.

- Market orientation: Research spin-offs supply very sophisticated goods and services that are not easily understood by customers. Researchers often 'fall in love' with their idea and make the mistake of considering the firm a mere tool for their personal goals - ignoring customers' desires and market feedback. This 'technological myopia' prevents the researcher from overcoming the technical dimension of the product and grasping its market potential (Brett et al., 1991; Piccaluga, 2001).

- Financial resources: To invest in a research spin-off is unquestionably risky; this is why it is not easy to find investors in the seed and start-up phases.

- Credibility and reputation: In the seed and start-up phases particularly, it is not easy to have a good enough reputation to attract the best human capital and to gain access to financial resources.

Academic incubators aim to fill these gaps to support research spin-offs in acquiring the necessary expertise to being their operation. Incubators foster entrepreneurial spirit inside the academic system, putting together talents, technology, capital, and know-how to favour the birth of innovative firms and the commercialisation of their products (Smilor and Gill, 1986).

The aphorism of Seneca (Epistolae, LXXI), "Ignoranti, quem portum petat, nullus suus ventus est" - that no wind is favourable if one does not know to which port one is sailing - can be effective in explaining the role of the incubation process. Universities create ships full of knowledge that float on the sea without a destination. These boats are devoid of tools that can support them in identifying the port they need to steer to and in showing them how to reach it. Accordingly, universities must not only generate knowledge, but also guide it, providing both a map of ports and the toolbox needed to set and follow the course. The map of ports synthesises information about the market. The products incorporate knowledge and technologies produced by academia and by the people and firms that utilise knowledge originating from academic research. This information is valuable in understanding the needs of the users of a university's knowledge, their motivations, and how it is possible to increase the utility to them.

An academic incubator intervenes in this stage, establishing a bridge between academia and the business context, helping to transform ideas into actions (Scharmer, 2009) and lowering the entrepreneurial risk of knowledge-rich, capital-poor start-ups.

\section{Methodology and data collection}

We have tested the VSA innovative firm incubation framework described above by analysing the empirical evidence through a single case study with embedded design. The 
analysis of the incubation process that takes place in the ARCA Consortium provided several interesting insights into the role of university incubators in fostering viability to the hosted firms.

The selection of the case study was based on theoretical sampling principles (Pettigrew, 1990), which require that the selection of cases is determined not by statistical generalisations but by their relevance to the research question and their ability to replicate the analytical framework that has been developed (Glaser and Strauss, 1967; Mason, 1996). A research design based on a single case may be considered appropriate when it is critical to confirm, question, or extend previously formulated theoretical propositions (Yin, 1994). The identified case study is characterised by an embedded design, which means that the case contains many units of analysis (Yin, 1994). We have thus performed an analytical generalisation to compare the empirical results of the cases with the template provided by the theory. Indeed, in considering the incubation process carried out within the ARCA Consortium, we focused our attention on the several spin-offs that had obtained the assistance, through different modalities (real or virtual), of the incubator's services from its foundation to 2011.

The focus on a single case study allowed us to explore it longitudinally, obtaining fine-grained information over a significant period of time. This is particularly relevant because of the high number of subunits of analysis (i.e., the various spin-offs) which have been hosted by the incubator of ARCA Consortium.

Data collection was based on three main categories of sources [triangulation of empirical evidence (Eisenhardt, 1989)]:

- information collected in the field through direct interviews with the administrative staff of the incubator

- interviews with managers of firms hosted by the ARCA Consortium through structured web-based questionnaires

- data extracted from the financial statements of firms for the years 2003 to 2011.

\section{The ARCA Consortium}

In June 2003, the ARCA Consortium was established by the University of Palermo, Italy, along with an association (Sintesi), a regional state-owned company (Sviluppo Italia Sicilia), and a private company (Easy Integrazione di Sistemi s.r.l.). The foundation of ARCA is an example of synergy between the private and the public sectors.

Sintesi is an association established in 1991 by the Sicilian Universities of Catania, Messina, and Palermo. The scope of the association is to promote cooperation between universities and private business in Sicily in the fields of education, innovation, and technological transfer. 
Sviluppo Italia Sicilia focuses its activities on Sicily, where it aims to promote the resources of the region. The firm operates with strong links to the regional government and supplies services for attracting investment and to improving the regional bureaucracy.

Easy Integrazione di Sistemi is a private firm established in 1996 as a spin-off of the Department of Physics of the University of Palermo. Its scope is to develop technologies for knowledge management and to develop innovative organisational models based on distance collaboration.

With the aid of $€ 1.8$ million from the Italian Ministry of Economic Development, the ARCA Consortium began a business incubator on the campus of the University of Palermo.

The ARCA incubator supplies services to help innovative entrepreneurial initiative overcome the so-called death valley phase (Auerswald and Branscomb, 2003), and to become competitive in the market.

The ARCA incubator delivers business planning services, equipped offices, marketing, and organisational and financial consulting. The incubator also acts as a hub to link the research spin-offs with potential stakeholders.

The incubator is also open to firms which already have their own offices and which are not interested in staying inside the incubator, but would like to take advantage of the business innovation network of ARCA, through 'virtual incubation'.

Virtual incubation involves the same services as in real incubation, but without the provision of office space. This allows firms to take advantage of all the incubator's common services and business network for a minimal cost; in particular, such firms are usually interested in the financial network.

Over about ten years of activity, the ARCA incubator has assisted 30 research spin-offs. Some of these ventures have been virtual incubation, others in real incubation and then on the market, while still others have been initially on real incubation and later in virtual incubation.

The ARCA incubator has supported the pre-incubation phases of several entrepreneurial initiatives participating in the 'Start Cup' contest - a part of the Italian National Prize for Innovation.

The 'Start Cup' award is a local contest for innovative BIs from scientific laboratories. The award was established in Palermo in 2005; the winners of the competition are invited to participate in the National Prize for Innovation.

At the end of 2013, 13 incubated firms have already completed the incubation period. 11 of these have been successful and are now able to stand alone in the business environment; only two failed to reach this goal. Another 17 start-ups are currently in the incubation process.

Table 1 shows the main characteristics of the start-ups that have been incubated by ARCA. 
Table 1 ARCA Consortium spin-offs

\begin{tabular}{|c|c|c|c|c|}
\hline Trade name & $\begin{array}{c}\text { Year of } \\
\text { establishment }\end{array}$ & $\begin{array}{l}\text { Sector of } \\
\text { activity (1) }\end{array}$ & $\begin{array}{l}\text { Currently under } \\
\text { incubation }\end{array}$ & $\begin{array}{l}\text { Finished } \\
\text { incubation }\end{array}$ \\
\hline BIONAT & 2003 & Biotech & - & $\mathrm{X}$ \\
\hline IN.TR.AM. (1) & 2005 & Transport & - & $\mathrm{X}$ \\
\hline WINGS & 2005 & ICT & - & $\mathrm{X}$ \\
\hline $\begin{array}{l}\text { WISENET } \\
\text { ENGINEERING }\end{array}$ & 2006 & $\begin{array}{l}\text { Diagnostic } \\
\text { equipment }\end{array}$ & - & $\begin{array}{c}\text { Virtual } \\
\text { incubation }\end{array}$ \\
\hline OPERA & 2006 & $\begin{array}{l}\text { Cultural } \\
\text { heritage }\end{array}$ & - & $\begin{array}{c}\text { Virtual } \\
\text { incubation }\end{array}$ \\
\hline IDRAMBIENTE (1) & 2006 & Environment & - & $\mathrm{X}$ \\
\hline DOCTOR GREEN & 2006 & Environment & - & $\mathrm{X}$ \\
\hline IRRIWORKS & 2006 & Environment & - & $\begin{array}{c}\text { Virtual } \\
\text { incubation }\end{array}$ \\
\hline SIN & 2006 & $\begin{array}{l}\text { Diagnostic } \\
\text { equipment }\end{array}$ & - & $\mathrm{X}$ \\
\hline SECURPROJECT & 2007 & ICT & - & $\mathrm{X}$ \\
\hline SOFTENERGY & 2007 & Environment & - & $\mathrm{X}$ \\
\hline CYCLOPUS CAD & 2007 & Biomed & - & $\mathrm{X}$ \\
\hline MOSAICOON & 2008 & ICT & \multicolumn{2}{|c|}{ Never incubated } \\
\hline BIOSURVEY & 2008 & Environment & $\begin{array}{l}\text { Under virtual } \\
\text { incubation }\end{array}$ & - \\
\hline DIASIS & 2008 & $\begin{array}{l}\text { Cultural } \\
\text { heritage }\end{array}$ & $\begin{array}{l}\text { Under } \\
\text { incubation }\end{array}$ & - \\
\hline I-LABS & 2008 & Energy & $\begin{array}{l}\text { Under virtual } \\
\text { incubation }\end{array}$ & - \\
\hline YAM & 2009 & Nautical & $\begin{array}{l}\text { Under virtual } \\
\text { incubation }\end{array}$ & - \\
\hline Gè & 2009 & Environment & $\begin{array}{l}\text { Under } \\
\text { incubation }\end{array}$ & - \\
\hline E.LAB & 2009 & Environment & $\begin{array}{l}\text { Under } \\
\text { incubation }\end{array}$ & - \\
\hline INFORMAMUSE & 2009 & ICT & $\begin{array}{l}\text { Under } \\
\text { incubation }\end{array}$ & - \\
\hline
\end{tabular}

Note: (1) Ceased the activity

Source: Our elaboration 
Table 1 ARCA Consortium spin-offs (continued)

\begin{tabular}{|c|c|c|c|c|}
\hline Trade name & $\begin{array}{c}\text { Year of } \\
\text { establishment }\end{array}$ & $\begin{array}{l}\text { Sector of } \\
\text { activity (1) }\end{array}$ & $\begin{array}{l}\text { Currently under } \\
\text { incubation }\end{array}$ & $\begin{array}{l}\text { Finished } \\
\text { incubation }\end{array}$ \\
\hline ABIEL & 2010 & Biotech & $\begin{array}{l}\text { Under } \\
\text { incubation }\end{array}$ & - \\
\hline SNAP & 2010 & Design & $\begin{array}{l}\text { Under } \\
\text { incubation }\end{array}$ & - \\
\hline FMOM & 2010 & Fashion & $\begin{array}{c}\text { Under } \\
\text { incubation }\end{array}$ & - \\
\hline KINEO & 2010 & Mechatronic & $\begin{array}{l}\text { Under virtual } \\
\text { incubation }\end{array}$ & - \\
\hline LYMPHA & 2010 & Environment & $\begin{array}{l}\text { Under virtual } \\
\text { incubation }\end{array}$ & - \\
\hline GEON & 2010 & Energy & $\begin{array}{l}\text { Under virtual } \\
\text { incubation }\end{array}$ & - \\
\hline LAB CP & 2010 & $\begin{array}{l}\text { Cultural } \\
\text { heritage }\end{array}$ & $\begin{array}{l}\text { Under virtual } \\
\text { incubation }\end{array}$ & - \\
\hline $\begin{array}{l}\text { CR MOBILITY } \\
\text { SOLUTIONS }\end{array}$ & 2010 & Energy & $\begin{array}{l}\text { Under virtual } \\
\text { incubation }\end{array}$ & - \\
\hline $\begin{array}{l}\text { MOBILITÀ } \\
\text { PALERMO }\end{array}$ & 2012 & Environment & $\begin{array}{l}\text { Under virtual } \\
\text { incubation }\end{array}$ & - \\
\hline $\begin{array}{l}\text { MARCELLO } \\
\text { MANCINI }\end{array}$ & 2012 & ICT & $\begin{array}{l}\text { Under virtual } \\
\text { incubation }\end{array}$ & - \\
\hline
\end{tabular}

Note: (1) Ceased the activity

Source: Our elaboration

\section{Decoding ARCA spin-offs with the VSA}

Spin-offs, especially in the seed and start-up phases, are firms of very small size that lack a well-defined structure. In these firms, almost all the functions are managed by a few people who together constitute the organ of governance. In other words, in these firms, it is not possible to identify specific internal subsystems as separated by the organ of governance. Hence, the organ of governance will be our focus for the internal analysis.

We will analyse the relevance of the shareholders (property) and the external relations with the suprasystems with which the spin-offs interact along their evolutionary path.

We also analyse this path from the perspective of the conceptual matrix model in order to demonstrate how research spin-offs may become VSs following, and as a result of, the incubation process achieving the viable characteristics of competiveness and consonance. 


\subsection{The scope of research spin-offs}

Spin-off firms are organisational systems created to pursue two main scopes:

- to survive (be viable) - as with any other human organisation

- to transfer and valorise research outside of university labs.

The latter is connected with the following relevant entities (suprasystems):

- the university - the suprasystem that generates the research on which the BIs are based

- the government - which is, or should be, interested in fostering the development and the innovation capacity of the country

- the labour market - as spin-offs need highly skilled workers

- the financial system - which supplies financial resources in exchange for expected payoffs.

The spin-off needs to be consonant with the suprasystems in order to pursue its goals. To achieve consonance, the spin-off must know and be aligned with the language and the rules of the suprasystems if it is to establish channels for the exchange of resources and to communicate with these suprasystems. The incubator is highly supportive of this process, as the incubated spin-off can take advantage of the channels that the incubator has already established with the suprasystems.

\subsection{The organ of governance in research spin-offs}

In a research spin-off, the organ of governance may be composed of one or more researchers and, sometimes, another component that possesses managerial skills.

When the organ of governance is composed of only researchers, these are the knowledge brokers (Golinelli, 2011). The presence of knowledge brokers allows the firm to continuously innovate while exploiting the market potential of these innovations. In fact, a firm with only one good and innovative BI will hardly be able to keep the advantage deriving from this innovation for a long time; hence, to maintain the viability of the firm, the innovation process should be a continuous process. Knowledge brokers act as bridges between the research labs and the market, ensuring an attitude of continuous innovation.

On the other hand, empirical studies (Monck et al., 1998) have shown how spin-offs managed only by researchers with little business experience tend to fail in the long term. This happens because researcher-entrepreneurs, despite their own high level of knowledge, lack the necessary managerial skills.

For these reasons, we believe that to gain a greater chance of viability, the organ of governance of research spin-offs should be composed of both researchers and skilled managers.

This mix is not easy to achieve in reality, for - as we observed in the case of the ARCA spin-offs - such firms are too small in the seed and start-up phases, and their Organs of Governance are often composed of a single researcher-entrepreneur. 
Of the 30 firms incubated by the ARCA incubator, 19 have an organ of governance lacking researchers; hence, only ten are actually managed and controlled by researchers. We thus observed 'knowledge governance' in only 33\% of the cases we analysed.

The reason for this can be traced to the regulations of the University of Palermo which indicate that researchers may administer and manage a research spin-off only if there is no interference with their research and teaching activities.

During the incubation period, the organ of governance is still in an embryonic stage and is directed by an organ of governance of the superior $(\mathrm{L}+1)$ level, composed by the tutors and consultants of the incubator.

While the imperfect composition of the organ of governance might not a problem during the incubation period, it can become a severe limitation on viability later, when the incubation period has finished.

\subsection{The property of research spin-offs}

According to the definition of a research spin-off given by Piccaluga and Balderi (2006), such a firm must be owned by at least one researcher. Hence, even if, as noted above, researchers might be not involved in the management of the firm, it is necessary that they are shareholders in the research spin-off.

ARCA spin-offs all take the form of limited liability companies ('società a responsabilità limitata, s.r.l.'). On average, there are five shareholders of ARCA spin-offs, while, as mentioned, the organ of governance is composed of only one person, who is also a shareholder in the firm.

It often happens that shares in research spin-offs are acquired by business angels and venture capitalists. These are usually temporary shareholders who will disinvest after some years in order to maximise their capital gains. During the period of their investments, these institutional investors often take part in the governance of the firm and become components of the organ of governance. As noted by Golinelli (2010), in these cases the organ of governance can be seen as an extended subsystem of governance composed by members belonging primarily to a suprasystem. This can become a problem following the disinvestment, and deep changes in the organ of governance may be required - hence of the strategy of the firm.

\subsection{Applying the conceptual matrix of the VSA to spin-offs}

According to the perspective of the VSA, the evolutionary path towards viability for research spin-offs begins with the BI aimed at gradual development towards becoming a VS, under the guidance and propulsive force of the organ of governance.

This process can be described as the 'reification' (from the Latin 'res' = thing) of the abstract BI into a concrete but flexible organisational structure.

The genesis of spin-offs has been described by Ndonzuau et al. (2002). The VSA adds to the model of Ndonzuau et al. the cyclical process of firm creation, which can be described with a spiral scheme. This scheme is relevant, because the firm creation process is continuous and involves feed-back and continuous reinterpretation by the organ of governance under a cyclical logic.

Following the path from the BI towards the viability of research spin-offs, we analyse each step according the VSA conceptual matrix model. 
- The $B I$ : This is the phase where the entrepreneurial idea is defined. In research spin-offs, it derives from the results of research. To transform research into a BI is no straightforward process, as research results are often far from the satisfying customers' desires. To transform research into a potential industrial application or a marketable product or service, the researcher needs to have an intuition or to be helped by some expert to find possible applications of his or her research findings. BIs that can be submitted to the ARCA incubator for selection may come from the laboratories of the University of Palermo or from external research structures, such as the National Research Council (CNR) or from students or alumni.

- The GOS: Before initiating the effort of formulating a business plan, it is necessary to be sure that the BI has commercial potential worth the effort. Hence, the BI must be well explicated by analysing and defining the product or service to be created, the technical prerequisites, the production process, the existence of substitute products or services, the size and characteristics of the target market, the profit and financial goals, and the market goals.

- The $L S$ : This is a formal representation of the BI. It represents the starting point for the later development of distinctive capabilities and of corporate identity and culture. In this phase, the GOS is formalised into a more structured general plan. In order to select potentially valuable BIs that deserve incubation, ARCA organised the Start Cup Palermo competition, in which researchers with entrepreneurial ideas can present their BIs to a jury of experts. Winners are selected on the basis of validity and feasibility, receiving an award of funds to start their activity and the chance to be accepted for incubation in ARCA.

- The PS: This is the crystallisation of the LS through the identification of human, technical, and financial resources that are able to carry out processes. In research spin-offs, although it is possible to define several roles and functions, the limited size of these firms means that it is not possible to attribute a role to each person working in the firm. Regarding the technical and financial resources, it is important to underline that, given the narrowness of investments, such firms would not be able to start entrepreneurial activity without the support of a business incubator.

- The ES: In order to emerge as accomplished systems, research spin-offs need to interact with contextual suprasystems, exchanging information, knowledge, materials, and energy. This capability depends on the degree of openness of the system, a feature that is directly proportional to its relational potential. Research spin-offs need to have a high degree of openness, as they are strongly dependent on the support of external incubation to overcome the seed and start-up phases.

- The DOS: At this stage, the organ of governance is involved in the design of possible relations and interactions between internal and external agents. It is in this phase that the spin-off seeks external support in the incubator and looks to the financial suprasystems for the intervention of business angels and venture capitalists.

- The SS: Once the incubator has accepted the BI and the GOS, the project passes to the business-planning phase. All the considerations above are included, formulating a complete and detailed business plan with a well-defined organisational scheme that depicts the SS. The business plan provides the details for the implementation of the 
BI. If the business plan is considered valid by the executive board of ARCA, the firm is established and the system-firm is born.

- The $V S$ : The incubation phase lasts for three years, during which time, the firm is supported and its managerial and technological know-how is gradually transferred to the organ of governance and the operational structure of the start-up firm. After incubation, the firm should have gained a state of viability allowing it to adapt and seek different states of equilibrium in the external context.

Figure 1 ARCA incubation phases (see online version for colours)

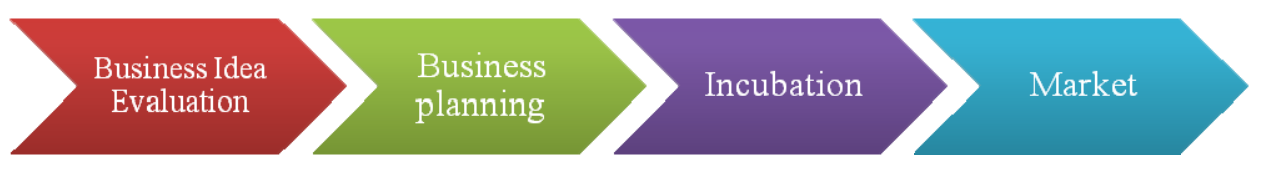

Source: Own work

\subsection{Intersystemic relations}

In order to propose an interpretative scheme of spin-off survival conditions in the context, the path outlined by the conceptual matrix has been supplemented with an analysis of intersystemic relationships with the main suprasystems.

According to the definition of the VSA, suprasystems are those systems in the context that exert influence, and at the same time detain a critical resource, for the observing system (Golinelli, 2010).

Figure 2 depicts the process through which spin-offs are incubated by ARCA and reach the market, along with the main channels of communication and exchange with the suprasystems. Within each suprasystem, we indicate the agents that play a key role in the path of transformation from BI to viable firm. In the market, we indicate the spin-offs that have already concluded the incubation process and are now VSs operating in the market.

Figure 2 also shows that research spin-offs incubated by ARCA are:

- Partially open: Since their establishment, and throughout their evolutionary path, they have engaged several relations with a number of contextual entities, exchanging knowledge, materials, financial resources, and energy, all of which are necessary to survive and to maintain a state of dynamical equilibrium. The degree of openness is at a maximum at the beginning, and gradually moves towards a certain level of closure, as controlled by the organ of governance. Hence, the organ of governance must be able to control and eventually limit the incoming flows so as to achieve the systemic goals.

- Contextualised: During the period of incubation, research spin-offs also interact with other incubating firms and with the suprasystems with which they seek consonance, with which they may engage in relations of resonance.

- Dynamic: Spin-offs are born and evolve through different systemic states, deriving from their self-organisation capability and from the decisions taken by the organ of governance. The arrow in Figure 2 indicates their evolutionary path. Research spin-offs are born as BIs in research laboratories, and evolve according to the 
choices and decisions taken by the organ of governance on the first level (L, the promoter of the BI, driving and governing the pre-incubation process and mediating with the $\mathrm{OoG}$ of level $\mathrm{L}+1$ in the incubation process) and the second level $(\mathrm{L}+1$, inside the incubator), towards their state of accomplished VS. In other words, the spin-off is an 'embryonic system' before and during the incubation period, when the OoG is not fully capable of governing all the dynamics of the system, and the other subsystems are missing. From this embryonic beginning, the spin-off develops throughout the other evolutionary states by increasing the governing capabilities of the OoG and the know-how of the operational structure towards its accomplishment as VS.

Figure 2 The path towards viability of spin-offs incubated in ARCA (see online version for colours)

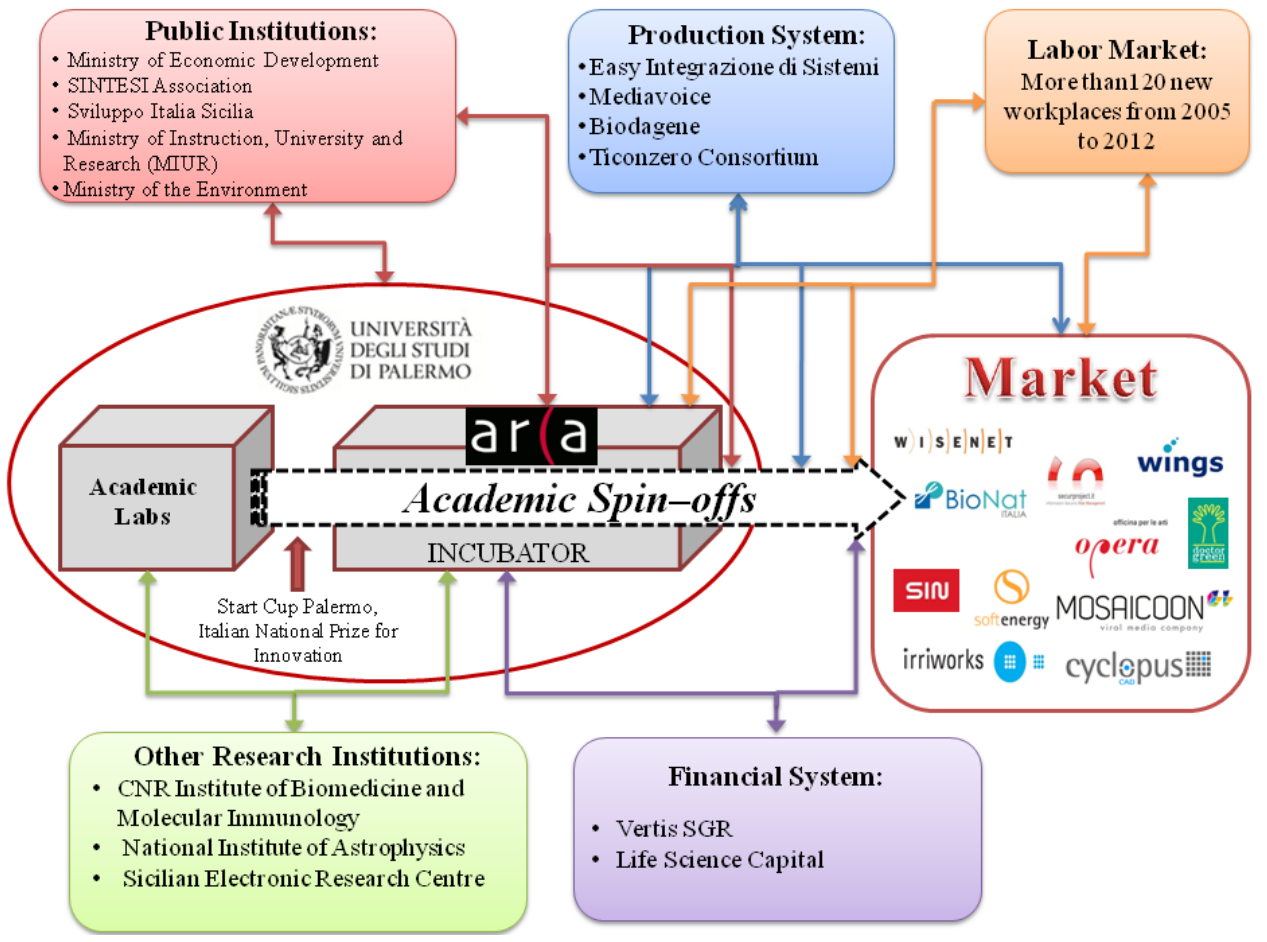

Source: Own work

\subsubsection{The relations of the spin-off with its closest suprasystem: the incubator}

The incubator represents the closest suprasystem for the incubated spin-off. During the incubation period, as we described, the incubator has the function of a second level $\mathrm{L}+1$ OoG. The task of this $\mathrm{L}+1 \mathrm{OoG}$ is to train the $\mathrm{L}$ level OoG of the firm until it acquires the necessary knowledge and governing capabilities to make autonomously viable decisions for the firm.

In Figure 2, the spin-off is depicted inside the incubator, unconnected to it by the arrows that associate the firm with the other suprasystems. This is because the spin-off represents a subsystem of the incubator; it is part of the incubator and resonant with it 
until the state of full viability is reached. The incubator acts as a kind of catalyst and as an intermediary of resources with regards to the major suprasystems, such as:

- The financial system: The incubator selects projects for prospective investors and acts as nominator for the selected projects.

- University: The incubator allows spin-offs to maintain strong relations with the university's departments and laboratories during the incubation process (Grandi and Grimaldi, 2001). This is of key relevance in the development phase of a prototype product, since the spin-off may thus obtain the knowledge and support of well-equipped advanced labs that it could not afford on its own

- Production system: Without the guarantee function of an incubator, it would be very difficult for a newborn firm, lacking historical records, to gain the trust of other firms (Doz and Williamson, 2002; Stinchombe, 1965; Dominici, 2008). A well-developed network, such as that of the incubator, allows the spin-off firm to:

- acquire complementary expertise that can be synergic with that of the founders

- obtain more funding

- expand the target market and improve the firm's image (Feola and Petrone, 2005).

- Other incubated firms: Physical incubation implies that the newborn spin-off and its staff work inside ARCA's offices. This creates cross-fertilisation, where the scientific and managerial consonance among spin-offs' staff can generate resonance and new entrepreneurial initiatives.

The success rate and the number of viable firms coming from the incubation are the main means of communicating the positive features of the incubator and increasing its credibility among the potential stakeholders (suprasystems) of the incubated spin-offs.

\subsubsection{The University of Palermo suprasystem}

The University of Palermo was established in 1805 , and with more than 65,000 students, is among the largest universities in Italy.

The 'relational bridge' (Golinelli, 2011) between the university suprasystem and the spin-off is the 'Spin-off Commission' of the University of Palermo. This commission is chaired by the Rector's delegate for spin-offs and is composed of the Rector himself, two professors, and one external member (chosen by the Rector).

The University of Palermo uses EU funds (POR 2000/2006) to give to the spin-offs equipped labs in the areas of mechanics, electronics, and graphics. These labs have been among the major drivers of success at the ARCA incubator.

\subsubsection{The public institution suprasystem}

Today, with the continuous and undiscriminating cuts to state funding of education and research (a process that, in Italy, began decades before the beginning of the actual crisis), knowledge transfer through new products and knowledge-based firms is also (or should become) one of the ways universities can find the resources they need to sustain their primary mission - the creation and diffusion of knowledge. On the other hand, to justify 
the cuts to education and research, the various governments passed several laws giving the university the ability and responsibility to manage new activities, such as the creation of spin-offs.

The collaboration between the university and the business environment should be one of the main ways in which universities find resources for research and education. Unfortunately, this is not the case with the University of Palermo (with very few minor exceptions), where the business systems are among the most underdeveloped in Italy and the EU. To become developed, the ARCA spin-offs cannot count on an enlightened industrial network supporting new activities, but they can take advantage of EU funding managed by the MIUR (the Italian Ministry of Research and Education).

The government has also promoted the establishment of university incubators via public funding plans for the incubators and for the incubated spin-offs.

Such government intervention has great significance in supporting the establishment of ARCA. In fact, as we mentioned above, ARCA was established by government agencies and private investors.

The incubator has been financed several times by the Ministry of Economic Development in the frame of specific government plans to finance spin-offs. Individual spin-offs incubated in ARCA have also been financed by government funds: Wings s.r.l. benefited from government aid from the Ministry of Education, while Softenergy s.r.l. has been assisted by the Ministry of Environment.

\subsubsection{The 'other research institution' suprasystem}

Non-academic research institutes play an important role in the framework of the national and local innovation system: they are usually focused on more technical research, compared to that performed by the universities. They may be useful in developing research spin-offs, both directly incubated and through collaboration with university labs. The Sicilian government provides incentives to this kind of collaboration. In the Palermo area, the ARCA incubator is open to this kind of synergy between university and government research centers; the results of this collaboration include Abiel s.r.l., a spin-off created by the university and the CNR (National Research Center).

Hence, the connections between incubated spin-offs and the 'other research institution' suprasystem concern both the research of government institutions and joint ventures between these and university laboratories.

\subsubsection{The financial suprasystem}

The financial suprasystem includes banks, stock exchanges, venture capitalists, and business angels. Banks are not eager to take on the high risk loaning to spin-off firms; such firms are usually too small to be able to enter the stock market. Venture capitalists and business angels are, however, particularly relevant to spin-offs. These are investors with a long-term horizon, who aim to take high risks in exchange for high rewards when the spin-off achieves viability. Although spin-offs have a high risk of failure, when successful, the gains on the invested capital are usually very high. For this reason, venture capitalists and business angels invest in many spin-offs, so that the small fraction of successful ventures can pay back the losses of the other risky investments and even provide a good margin of profit. 
Moreover, these investors also give other kinds of support to spin-offs: business angels in particular provide a wide range of managerial supporting activities to start-ups.

The financial suprasystem is usually well linked to the incubator (as in the case of ARCA). In the incubators, venture capitalists can find an excellent reservoir of selected start-ups for their investment.

In order to help investors find spin-offs and vice versa, ARCA promotes and organises several meetings in the form of 'elevator pitches'. So far, two spin-offs have been financed by venture capitalists through this kind of meeting. This result - which could appear irrelevant in other, more evolved economic environments - in fact constitutes a great success, if we remember that ARCA is operating in one of the most economically depressed areas of Europe. ARCA has an agreement with Vertis SGR, which has the privilege to choosing ARCA spin-offs to invest in. In some cases, such as that of Abiel s.r.l. (whose shares were bought by Life Science Capital), the interest of the venture capitalist has been known since the firm was established.

For the reasons above, Figure 2 shows both cases with arrows linking the financial suprasystem directed with both the incubator and the spin-off.

\subsubsection{The labour market suprasystem}

The technological transfer needs highly qualified human resources. Highly skilled staff must work in the incubator to give qualified assistance to start-ups, and must also be present in new spin-off firms.

The labour market in Sicily can offer many highly skilled young workers: typically, these workers need to emigrate to other Italian regions or abroad in order to find a job to fit their skills - this is the sad phenomenon of 'brain drain', common all over Italy, and of dramatic intensity in Sicily (where the unemployment rate for young people under 25 years old is over $40 \%$ and rising, according to ISTAT) and other depressed areas. Research spin-offs are an excellent chance to avoid this phenomenon; although the number of young brains employed in this kind of firm is still statistically irrelevant, it could nonetheless represent a hope for the future.

Figure 2 shows the links of the job market suprasystem with ARCA, with the spin-offs, and with the market, where the new job opportunities are created by spin-offs.

\subsubsection{The production suprasystem}

To achieve viability, the spin-offs need to seek consonance with the production system, through collaboration with other firms in the business environment with the aim of developing a reliable supply chain. These partnerships are of great importance for the viability of the newborn spin-offs, since they can provide access to information, to resources, to markets, and to technologies - hence giving credibility to the new entrepreneurial venture through the development of a business network (Baum et al., 2000; Doz and Williamson, 2002; Feola and Petrone, 2005; Gulati et al., 2000; Sarkar et al., 2001; Stuart et al., 1999; Stinchombe, 1965).

Unfortunately, in Sicilian business systems, there are very few chances of creating a good business network, as there are very few firms that really care about technological issues and have interests in research spin-offs. In spite of these limitations of the economically depressed environment, ARCA was able to promote the link between its spin-off, Bionat, and Mediavoice s.r.l. - a Sicilian firm specialising in vocal technologies. 
Figure 2 shows the links between the production system, the incubator, and the spin-off firms.

\subsection{Competitiveness and consonance of ARCA's spin-offs}

Competitiveness and consonance are the main drivers of viability (Golinelli, 2010). The former is the force that aims the firm towards continuous performance improvements, seeking superiority over and differentiation from competitors (Dominici, 2010). The latter is the quest for harmony with the subsystems and suprasystems. This can be achieved through a common language, a common culture, and common behaviours that can serve as a basis for the development of relations.

Viability does not depend only on resources and structure, but also on the quality of the relations and interactions that the firm is able to establish with the actors in the context.

The organ of governance must seek these goals by observing and contextualising the information coming from the environment, and by taking actions to adapt the firm's structure.

In order to assess the competitiveness of ARCA Consortium spin-offs, we have considered EBITDA as an indicator of performance. EBITDA is useful for measuring whether a firm is able to generate wealth through operations alone - excluding budgetary policies and fiscal interferences, which do not always give an accurate picture of a company's performance.

Looking at the aggregate time series of EBITDA since 2003 (the year the first incubated firm was founded) to 2011 , we can conclude that all the enterprises in the ARCA Consortium showed an increasing trend of performance both during and after incubation.

Table 2 shows how firms that have completed the incubation period generate higher levels of EBITDA compared to companies that are still incubating. This is a hint that incubation allows firms to reach higher levels of economic and financial stability factors which lie at the base of enterprise viability.

Consonance, however, is not easy to measure, since it considers a wide variety of elements that are not of a quantitative or accounting nature. The only way to evaluate consonance is to consider qualitative data, such as behaviours, implemented strategies and tactics, number and typology of ventures, and agreements - all of which might give hints about the attitude of the OoG and the response of the actors in the context.

At the beginning of the process of structural definition, competitiveness is configured as a distant goal to be achieved, while consonance is a distant goal to be achieved at the end of the process, when the company has become more independent from the actors who have generated and supported it along its evolutionary path.

To obtain this qualitative data, we plunged into the incubator's business environment and conducted interviews and conversations with the directors of the incubated companies and the administrative staff of the incubator over a period of three months.

On the basis of the considerations that emerged from the interviews and from conversations with people involved in the incubator, we can argue that ARCA spin-offs show a tension towards the search for harmony, even at the end of the incubation period. This is something we could find in all the ARCA spin-offs that are still operating in the post-incubation stage. Many of these firms also prefer to maintain strong links with ARCA following incubation, as they see ARCA as a hub of useful relations for 
consonance with the suprasystems. In case of spin-offs which have been financed by venture capitalists - such as Mosaicoon s.p.a. and Abiel s.r.l. - consonance has been reached thanks to the links of the venture capitalists. We can draw similar conclusions for Bionat s.r.l., Gè, and Informamuse, whose shares have been bought by other firms that supplied their links for consonance.

Due to their nature as highly innovative enterprises, ARCA spin-offs have a positive impact on the territory, which, thanks to their presence, can develop economically, socially, and also from an environmental perspective. In addition, we should consider that, from 2003 to 2011, ARCA spin-offs have generated revenues of $€ 11,154,000$, have filed several patents, and have created almost one hundred and fifty jobs. These data may look irrelevant considered in the context of a highly developed area, but they have a particular significance if we consider that they operate counter to the tendency in the underdeveloped economic context of Sicily.

In conclusion, although the level of consonance is even more difficult to maintain at the end of the incubation period, the category of the spin-off firm is incapable of maintaining a separate existence from its context. For the above reasons, we can assert that the spin-offs incubated in ARCA achieved a state of viability given their ability to be competitive in the market and consonant with the context.

Table 2 Aggregated EBITDA generated by ARCA spin-offs (2003-2011)

\begin{tabular}{|c|c|c|c|c|c|}
\hline & 2003 & 2004 & 2005 & 2006 & 2007 \\
\hline \multirow[t]{2}{*}{ Incubating spin-offs } & $€ 64,235$ & $€ 40,954$ & $€ 71,417$ & $€ 65,261$ & $€ 120,015$ \\
\hline & 1 firm & 1 firm & 2 firms & 6 firms & 9 firms \\
\hline \multirow[t]{2}{*}{ Post-incubation spin-offs } & - & - & - & - & - \\
\hline & - & - & - & - & - \\
\hline \multirow[t]{3}{*}{ Total } & $€ 64,235$ & $€ 40,954$ & $€ 71,417$ & $€ 65,261$ & $€ 120,015$ \\
\hline & One firm & One firm & Two firms & Six firms & Nine firms \\
\hline & 2008 & 20 & & 10 & 2011 \\
\hline \multirow[t]{2}{*}{ Incubating spin-offs } & $€ 287,875$ & $€ 44$ & &, 374 & $€ 142,936$ \\
\hline & 12 firms & $10 \mathrm{fi}$ & & ïms & 15 firms \\
\hline \multirow[t]{2}{*}{ Post-incubation spin-offs } & - & $€ 348$ & 44 & 6,942 & $€ 560,895$ \\
\hline & - & 6 fir & & irms & 10 firms \\
\hline \multirow[t]{2}{*}{ Total } & $€ 287,875$ & $€ 392$ & 98 & 8,316 & $€ 703,831$ \\
\hline & 12 firms & $16 \mathrm{fi}$ & & ïms & 25 firms \\
\hline
\end{tabular}

Notes: The aggregate data do not include the financial statements of Sin s.r.l. for 2007 or those of CR Mobility Solution Systems s.r.1. for 2011, as they were not available at the time of the survey. Nevertheless, these two firms were included in the calculation of the number of firms. The company Doctor Green Salvatore Bellavista \& Co. sas was totally excluded from this analysis, because it is a partnership; hence, it is not required to publish annual financial statements. IN.TR.AM. s.r.l. and Idrambiente s.r.l. were also excluded from the analysis, as they ceased activity.

Source: Own work, based on financial statements from ARCA Consortium firms. 


\section{Conclusions}

We analysed the research spin-offs that have been incubated by the ARCA Consortium's incubator at the University of Palermo, Italy in the light of the VSA, in order to answer to the research question, 'Can ARCA spin-offs obtain the status of viable firms following the incubation process?'

The VSA helped to highlight the key relations between the incubator, the spin-offs, and the relevant agents in the business context. This analysis has been very useful in answering the research question, but also in better understanding the dynamics of the incubation process for research spin-offs.

We have found that, in spite of the economically depressed context (Sicily being one of the poorest and least industrialised regions in the EU, with a decreasing economic trend over the last decades), the spin-offs were able to reach a state of viability after incubation.

As a consequence, we can assert that the added value of the ARCA incubator for spin-offs is given by its laboratory function of supporting the transformation of ideas into actions, lowering the entrepreneurial risk. In other words ARCA acts as a greenhouse in the desert within the underdeveloped Sicilian business context. Indeed, as a greenhouse, ARCA gathers people and innovative ideas and allows them to confront each other and interact in a fertile environment. As a result, entrepreneurs are able to overcome the isolation that typifies undeveloped contexts, and they sustain each other, thus increasing their chances of success. ARCA's challenge is to combine and integrate the different pieces of knowledge pertaining to both the incubated firms and ARCA's consultants, in order to stimulate cross-fertilisation.

We are aware that this study has several limitations, namely:

- The use of aggregate balance-sheet accounting data for the competitiveness analysis does not allow conclusions to be drawn on the level of competitiveness achieved by each individual single firm. In addition, the financial statement analysis, based on current data, cannot provide information about the future situation of the businesses, which may be influenced by fiscal policies or affected by subjectivity in the evaluation of the estimated and conjectured values.

- Competitiveness is multidimensional, and should be assessed in relation to other indicators, apart from EBITDA.

- We have not used a quantitative method to measure the level of consonance achieved by spin-off companies with the context.

On account of these limitations, we plan to develop further research on this topic, in order to extend the competitiveness analysis to other indicators and to better analyse the level of consonance; also, through statistical and mathematical tools such as fuzzy logic, we will measure the level of consonance with each firm's actors.

\section{Disclaimer}

To conform with Italian regulations on academic publishing, even though the article is the joint work of the authors, we attribute the contribution of each author as follows: 
Sections 1, 2, 5, 6.1-6.4, 6.6 and 7 can be credited to Gandolfo Dominici and Sections 3, 4 and 6.5 to Gabriella Levanti.

\section{Acknowledgements}

The authors wish to thank Professor Umberto La Commare, President of the ARCA Consortium, for giving us the opportunity to analyse the ARCA Consortium incubator. In addition, we would like to thank the management of the ARCA spin-offs for their valuable time and for their useful information that made this study possible. We also thank the former PhD student and Secretary of B.S.Lab Dr. Federica Palumbo for her valuable contribution in the earlier stages of this research.

\section{References}

Auerswald P. and Branscomb L. (2003) 'Valleys of death and Darwinian seas: financing the invention to innovation transition in the United States', Journal of Technology Transfer, Vol. 28, Nos. 3-4, pp.227-239.

Barile S. and Di Nauta P. (2011) 'Viable systems approach for territory development', in AA.VV (Eds.): Contributions to Theoretical and Practical Advances in Management. A Viable Systems Approach (vSa), pp.199-243, International Printing, Avellino.

Barile S. and Gatti, M. (2007) 'Corporate governance e creazione di valore nella prospettiva sistemico-vitale', Sinergie, No. 73-74, pp.151-168.

Barile S. and Polese F. (2010) 'Smart service systems and viable service systems', Service Science, Vol. 2, No. 1, pp.21-40.

Barile S. and Polese F. (2011) 'The viable systems approach and its potential contribution to marketing theory', in V.A. Contributions to Theoretical and Practical Advances in Management. A Viable Systems Approach (vSa), pp.139-172, International Printing, Avellino, Italy.

Barile, S. (2008) L'impresa Come Sistema - Contributi sull'Approccio Sistemico Vitale, 2nd ed., Giappichelli, Torino.

Baum J., Calabrese T. and Silverman B. (2000) 'Don't go it alone: alliance networks in Canadian biotechnology', Strategic Management Journal, Vol. 21, No. 3, pp.267-294.

Beer, S. (1975) 'Preface', in Maturana H.R. and Varela, F.J. (Eds.): Autopoietic Systems, BLC Report 9, University of Illinois.

Brett, A., Gibso, D. and Smilor, R. (1991) University Spin-off Companies, Rowman and Littlefield, Maryland.

Chesbrough, H.W. (2003) Open Innovation: The New Imperative for Creating and Profiting from Technology, Harvard Business School Press, Boston.

Chiesa, V. and Piccaluga, A. (1998) 'La Nascita di Imprese ad Alta Tecnologia', Impresa \& Stato, Vol. 43 [online] http://impresa-stato.mi.camcom.it/im_43/chiesa.htm.

Christopher, W.F. (2007) Holistic Management - Managing What Matters for Company Success, Wiley-Interscience, Hoboken.

Dominici, G. (2008) 'Demand driven supply chain ed innovazione: il sistema logisitico-produttivo per la soddisfazione del cliente', in Purpura, A. and Fazio, G. (Eds.): Economia e Gestione dell'Innovazione nelle PMI, pp.100-114, Franco Angeli, Milano.

Dominici, G. (2010) From Business System to Supply Chain and Production in Japan. Lean Production and Its Roots in Japanese Business Culture, VDM Verlag Dr. Muller, Aktiengesellschaft \& Co. KG. 
Dominici, G. and Palumbo, F. (2013) 'Decoding the Japanese lean production system according to a viable systems perspective', Systemic Practice and Action Research, Vol. 26, No. 2, pp.153-171.

Doz, Y.L. and Williamson, P. (2002) Alliances As Entrepreneuship Accelerators, Working Paper INSEAD [online] http://flora.insead.edu/fichiersti_wp/inseadwp2002/2002-18.pdf.

Eisenhardt, K. (1989) 'Building theories from case study research', Academy of Management Review, Vol. 14, No. 4, pp.532-550.

Etzkowitz, H. (2001) 'The second academic revolution and the rise of entrepreneurial science', Technology and Society Magazine, IEEE, Vol. 20, No. 2, pp.18-29.

Etzkowitz, H. and Leydesdorff, L. (2000) 'The dynamics of innovation: from national systems and to a triple helix of university-industry-government relations', Research Policy, Vol. 29, No. 2, pp.109-123.

Etzkowitz, H., Webster, A., Gebhardt, C. and Terra, B.R.C. (2000) 'The future of the university and the university of the future: evolution of ivory tower to entrepreneurial paradigm', Research Policy, Vol. 29, No. 2, pp.313-330.

Feola, R. and Petrone, M. (2005) 'Impresa spin-off e acquisizione di risorse. Il ruolo dell'incubatore accademico', Esperienze d'Impresa, Vol. 1, pp.39-58.

Glaser, B.G. and Strauss, A.L. (1967) The Discovery of Grounded Theory, Aldin, Chicago.

Golinelli, G.M. (2010) Viable Systems Approach - Governing Business Dynamics, Kluwer/CEDAM, Padova.

Golinelli, G.M. (2011) L'Approccio Sistemico al Governo dell'Impresa. Verso la Scientificazione dell'Azione di Governo, Cedam, Padova, Vol. II.

Grandi, A. and Grimaldi, R. (2001) 'The contributions of university business incubators to new knowledge-based ventures', Industry and Higher Education, Vol. 15, No. 4, pp.239-250.

Gulati, R., Nohria, N. and Zaheer, A., (2000) 'Strategic networks', Strategic Management Journal, Vol. 21, No. 3, pp.203-215.

Hwang, V.W. and Horowitt, G. (2012) The Rainforest: The Secret to Building the Next Silicon Valley, Regenwald.

Lockett, A., Siegel, D., Wright, M. and Ensley, M.D. (2005) 'The creation of spin-off firms at public research institutions: managerial and policy implications', Research Policy, Vol. 34, No. 7, pp.981-993.

Lockett. A., Wright, M. and Franklin, S. (2003) 'Technology Transfer and universities' spin-out strategies', Small Business Economics, Vol. 20, No. 2, pp.185-200.

Mason, J. (1996) Qualitative Reasoning, Sage, Londra.

Maturana, H.R. and Varela, F.J. (1975) Autopoietic Systems, BLC Report 9, University of Illinois, Urbana.

Miller, J.G. (1978) Living Systems, McGraw-Hill, New York.

Monck, C., Quintas, P., Porter, R., Storey, D. and Wynarczyk, P. (1998) Science Parks and the Growth of High-Technology Firms, Croom Held, Londra.

Moray N. and Clarysse B. (2005) 'Institutional change and resource endowments to science based entrepreneurial firms', Research Policy, Vol. 34, No. 7, pp.643-659.

Ndonzuau, F.N., Pirnay, F. and Surlemont, B. (2002) 'A stage model of academic spin-off creation', Technovation, Vol. 22, No. 5, pp.281-289.

Pettigrew A.M. (1990) 'Longitudinal field research on change. Theory and Practice', Organization Science, Vol. 1, No. 3, pp.267-292.

Piccaluga A. (2001) La Valorizzazione della Ricerca Scientifica. Come Cambia la Ricerca Pubblica e Quella Industriale, Franco Angeli, Milano.

Piccaluga, A. and Balderi, C. (2006) Consistenza ed Evoluzione delle Imprese Spin-off della Ricerca Pubblica in Italia, Rapporto di Ricerca del Laboratorio IN-SAT della Scuola Superiore Sant'Anna per Finlombarda s.p.a., IN-SAT Lab, 25 September. 
Sarkar, M., Echambadi, R. and Harrison J. (2001) 'Alliance entrepreneurship and firm market performance', Strategic Management Journal, Vol. 22, Nos. 6-7, pp.701-711.

Scharmer C.O. (2009) Theory U: Leading from the Future as It Emerges, Berrett-Kochler Publishers.

Smilor, R. and Gill, M. (1986) The New Business Incubation: Linking Talent, Technology, Capital and Know-how, Lexington Books.

Stinchombe, A.L. (1965) 'Social structures and organizations', in March, J.G. (Ed.): Handbook of Organizations, pp.142-193, Rand Mc Nally, Chicago.

Stuart, T.E., Hoang, H. and Hybels, R.C., (1999) 'Interorganizational endorsements and the performance of entrepreneurial ventures', Administrative Science Quarterly, Vol. 44, No. 2, pp.315-349.

Thursby, J. and Thursby, M. (2002) 'Who Is selling the ivory tower? Sources of growth in university licensing', Management Science, Vol.48, No. 1, pp.90-104.

Wright, M., Birley, S. and Mosey, S. (2004a) 'Entrepreneurship and university technology transfer', The Journal of Technology Transfer, Vol. 29, No. 3-4, pp.235-246.

Wright, M., Vohora, A. and Lockett, A. (2004b) 'The formation of high-tech university spinouts: the role of joint ventures and venture capital investors', Journal of Technology Transfer, Vol.29, Nos. 3-4, pp.287-310.

Yin, R.K. (1994) Case Study Research, 2nd ed., Sage, Thousand Oaks, CA.

\section{Notes}

1 The ARCA (Applicazione della Ricerca e la Creazione di Aziende innovative, that is, the Application of Research and the Creation of Innovative Firms) Consortium was established in 2003 by a public-private partnership with the specific mission of managing a science-based business incubator. The outcomes of incubator's activities are the creation of qualified and sustainable jobs and the promotion of the development of Sicily - one of the most underdeveloped regions in southern Italy. From its foundation, the ARCA incubator has helped more than 35 innovative start-ups. 